\title{
Research on Teaching Evaluation Model of Public Security Information Management Course
}

\author{
Liang $\mathrm{Hu}$ \\ Department of Humanities and Management, JiangXi Police College, NanChang, China
}

\begin{abstract}
Public security information management courses teaching quality monitoring system based on network proposed teaching network management state of mind, realizes the analysis of the data in the classroom teaching activities, formed a "evaluation, evaluation of teaching and evaluation" three assessment oneness, full participation in the classroom teaching quality supervision and control mode, construction and implementation of the monitoring system of teaching quality of the public security colleges and universities in China, there is a certain reference value.
\end{abstract}

Keywords-teaching quality; public security; information management course; network

\section{INTRODUCTION}

After years of teaching practice, the public security colleges and universities have gradually established and improved the teaching quality monitoring system, including the quality control of the teaching quality[1][2]. For classroom teaching quality monitoring, before class, in class and after class combination of process monitoring model is adopted[3]. And before the class monitor includes course talents training plan, curriculum standards, qualifications of teachers, new curriculum lessons, lesson plans, teaching materials; in the course of monitoring, including class leaders, supervision classes, teachers lessons, information feedback, mid-term evaluation etc.; after-school monitoring including paper checks, performance analysis, students' teaching evaluation, quantitative evaluation etc.. But the classroom teaching attention was also weak, incomplete coverage evaluation index, the evaluation index of paying too much attention to teaching and teachers, and less attention to classroom teaching environment, teaching facilities and students' learning status[4][5].

Accordingly, this paper while maintaining the original monitoring system based on the constructed in the construction of classroom teaching network state information database as the foundation, to classroom teaching network state information analysis as a means to semester classroom teaching activities in network monitoring and management model for the classroom teaching quality monitoring[6][7].

\section{Public SECURITy InFORMATION MANAGEMENT Course TEACHING Evaluation MODEL}

Based on the network information security management course teaching quality monitoring system mainly includes classroom teaching state information collection, quantitative evaluation of data analysis and statistics, data analysis, internal and external supervision of state monitoring and analysis of week lectures characters of classroom teaching evaluation and students' stage achievement and learning condition analysis, as shown in Figure I.

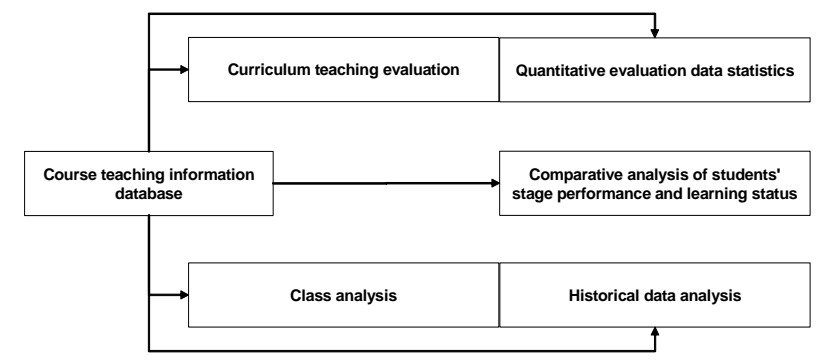

FIGURE I. PUBLIC SECURITY INFORMATION MANAGEMENT COURSE TEACHING EVALUATION MODEL

The teaching database not only were collected basic information of full-time teachers and school part-time teachers, part-time teachers, at the same time according to the schedule dynamic generation of classroom teaching information collection form a lecture record. The lecture record table is more concerned with the collection of classroom activity information than the traditional record form which is mainly based on curriculum evaluation, as shown in Table I.

TABLE I. LECTURE RECORD

\begin{tabular}{ll}
\hline \multicolumn{1}{c}{ Item } & \multicolumn{1}{c}{ Information field } \\
\hline Lecture staff & Name, Unit, Class location, Time, Date \\
Teacher & Name, Title, Course name, Title, Substitute \\
Teaching types & Writing on the blackboard, Questions, Exercises \\
Student status & $\begin{array}{l}\text { Class attendance, Attendance, Classroom order, } \\
\text { Student behavior }\end{array}$ \\
Teaching link & Naming, Interactive teaching \\
Classroom \\
environment \\
$\begin{array}{l}\text { Teaching } \\
\text { evaluation }\end{array}$
\end{tabular}

The characteristics of public security information management course network teaching quality monitoring model based on: The first is the establishment of the information database will contribute to the accumulation of 
teaching information, teaching management, teaching, teachers' professional ability, students' learning state of special and detailed comparative analysis for the faculty construction of teaching management, and the construction of style of study provide targeted advice. The second is in the mechanism to achieve full implementation of the evaluation, monitoring and evaluation of the quality of classroom teaching of information technology.

\section{EVALUATION INDEX SYSTEM OF PUBLIC SECURITY INFORMATION MANAGEMENT COURSE}

Public security information management course teaching evaluation index system based on the university computer basic course classroom teaching elements and characteristics of the development of specific index, the corresponding evaluation and assessment type. The curriculum evaluation index system is composed of two levels. The first layer is composed of teaching preparation, classroom management, teaching content, teaching method, teaching interaction, teaching reform and teaching effect. The second layer index is the evaluation index of the seven parts. The evaluation index system of computer basic course is related to the high quality of the evaluation index. The evaluation index score is determined mainly by comparison, relating to the teaching quality of higher degree of factors as evaluation indicators to determine the weight of the connotation, and then conduct research on the evaluation of experts, through the trial, the evaluation indicators of the evaluation, research and comprehensive and final scores are shown in Table II.

TABLE II. EVALUATION INDEX OF PUBLIC SECURITY INFORMATION MANAGEMENT COURSE

\begin{tabular}{|c|c|c|c|}
\hline No. & Index & Scoring criteria & Score \\
\hline 1 & $\begin{array}{l}\text { Teaching } \\
\text { work }\end{array}$ & Details of teaching materials & 10 \\
\hline 2 & $\begin{array}{l}\text { Classroom } \\
\text { management }\end{array}$ & $\begin{array}{l}\text { Serious organization of teaching, } \\
\text { strict classroom management, good } \\
\text { classroom discipline }\end{array}$ & 10 \\
\hline 3 & $\begin{array}{l}\text { Content of } \\
\text { courses }\end{array}$ & $\begin{array}{l}\text { Rich content, to meet the } \\
\text { requirements of the syllabus }\end{array}$ & 25 \\
\hline 4 & Lecture type & $\begin{array}{l}\text { Logic of teaching is strong, vivid and } \\
\text { fluent }\end{array}$ & 20 \\
\hline 5 & $\begin{array}{l}\text { Teaching } \\
\text { interaction }\end{array}$ & $\begin{array}{l}\text { To mobilize the students to think, } \\
\text { good interactive effect }\end{array}$ & 10 \\
\hline 6 & $\begin{array}{l}\text { Teaching } \\
\text { reform }\end{array}$ & Inquiry and discussion teaching & 15 \\
\hline 7 & $\begin{array}{l}\text { Teaching } \\
\text { effectiveness }\end{array}$ & $\begin{array}{l}\text { Teaching characteristic is bright, } \\
\text { strong attraction }\end{array}$ & 10 \\
\hline
\end{tabular}

IV. Management Tactics of Teaching Model of PUBLIC SECURITY INFORMATION MANAGEMENT COURSE

In the teaching management software to optimize the whole teaching staff information, course information, address information, import student information, and their respective binding. On the one hand, since the fourth week teaching, supervisors will lecture records entry system and stored in the database, and then through the leadership of class teaching reform, the formation of classroom teaching quality monitoring meridians; on the other hand, the students held a forum, teachers and students face to face learning problems, explore learning methods, improve the learning ability in students as the main body for online teaching evaluation and teacher centered online rating tube, the teachers and the teaching management staff in qualitative data analysis through the quantitative score, both for assessment can also be through the analysis of the data structure of teachers over the years, are formed on the monitoring of classroom teaching, construction of college information management curriculum based on public security network monitoring system of teaching quality.

The public security information management curriculum model has the following advantages:

First, the evaluation index of the setting has different levels and dimensions, such as the first level indicators, two indicators. On the teaching of teachers of different titles, different requirements, set of indicators is effective and guidance.

Second, not only pay attention to the evaluation results, also pays attention to the whole evaluation process, pay attention to communication between evaluators and evaluate, aimed at strengthening the teaching and teaching benefits teachers as well as students. Between teachers and students, achieve the goal of improving together, is conducive to the elimination of Teachers is dynamic, help to mobilize the enthusiasm of teachers.

Third, to all the teachers to give equal attention to each teacher's teaching characteristics and teaching ability development, to promote teachers to play their own strengths, the formation of a unique teaching style.

Fourth, in the evaluation index of the setting, the main concern is the teaching of teachers in the teaching objectives of the rationality, the completion of scientific and teaching objectives and students learning situation of self evaluation.

Fifth, the angle of evaluation is mainly to cultivate students' achievements in theory, method, ability and emotional attitude obtained, namely evaluation by single evaluation from the perspective of teachers' teaching to the development of teachers' teaching and students' learning from two aspects of evaluation.

Sixth, the evaluation results and the teachers meet, give appropriate incentives for good teachers, and arrange the excellent teachers in public speaking classes; the problems of teachers' teaching, through teaching, teaching and research in the class and the students held a forum to listen to opinions, to gradually improve the teaching level.

Seventh, in the teaching effect, to avoid the heavy test results, students usually learn the situation.

\section{DISCUSSION AND FUTURE WORK}

Although the public security information management course teaching quality monitoring model is proposed to promote the construction of teachers teaching style and study 
style, and so on, but there are also some shortcomings, mainly in a few teachers do not pay enough attention to the evaluation work, have to cope with the phenomenon. Therefore, in the future research work needs to be carried out on the evaluation of the implementation and evaluation of the results of the use of further discussion and improvement.

\section{ACKNOWLEDGMENT}

This author's work is supported by JiangXi Research on teaching reform of higher education(JXJG-15-19-3), JiangXi Science and technology research project of Education Department(GJJ151193), JiangXi Social Science Planning Projects during the 12th Five-Year Plan(14TQ05) and JiangXi Police College Scientific Research Project(2014QN001).

\section{REFERENCES}

[1] Xu Jianguo. Research on the innovation and construction of information management and information system [J]. Modern Intelligence, 2007 (10). (in Chinese)

[2] Gao Li. The reform of the teaching system of computer information management system [J]. China Marke, 2016 (05). (in Chinese)

[3] Zhao Jiaojie. The innovation of curriculum system of information management [J]. Information Technology, 2013 (36). (in Chinese)

[4] Zhigang Zhao. Research on teaching reform of management information system [J]. Modern Trade and Industry, 2011 (02). (in Chinese)

[5] Zhang Jiwen. The analysis and design of the curriculum system of information management and information system [J]. Computer Education, 2005 (08). (in Chinese)

[6] Su Yuzhao. Construction of information management major [J]. University Education, 2013 (24). (in Chinese)

[7] Liu Tingting. Research on the professional training mode of information management and information system in the era of big data [J]. China Electric Power Education, 2014 (02). (in Chinese) 